\title{
İş Stresi ve Eskişehir Osmangazi Üniversitesi İdari Personel Üzerine Bir Araştırma
}

\section{Hüseyin GÜRBÜZ1}

$\ddot{O} z$

Günümüzün en önemli sorunlarından biri olan stres ve stresin iş yaşamındaki etkileri strese maruz kalan kişiler üzerinde önemli sorunlara yol açmaktadır. Stres kişinin etkinliğini ve verimliliğini farklı yönlerde etkileyen bir kavram olarak ortaya çıkmaktadır Bu çalışmada, stres kavramı, iş stresi ve kaynakları üzerinde durulmuş ve Eskişehir Osmangazi Üniversitesi'nde çalışan idari personel üzerine uygulanan bir araştırma ile çalışanlarda strese neden olan faktörler belirlenmeye çalıșılmıștır. Ayrıca strese neden olan faktörler yapısal eșitlik modeliyle (YEM) test edilmiştir. Araştırma sonucunda, strese neden olan en önemli faktörün iş koşullarından kaynaklandığı belirlenmiştir.

Anahtar Kelimeler: Stres, İşs stresi, Faktör analizi, Varyans analizi, Yapısal eşitlik modeli, İdari personel

\section{Work Stress and a Research on the Administrative Staff of Eskisehir Osmangazi University}

\begin{abstract}
One of the most important problems of today, stress and stress in business life causes important problems on people exposed to stress. Stress is a concept that affects the effectiveness and efficiency of a person in different ways. In this study, the stress concept, work stress, and stress resources are emphasized and a research was applied on the administrative staff working at the Eskişehir Osmangazi University and which factors that cause stress are tried to be determined. In addition, stress factors were tested with structural equation model (SEM). As a result of the research, it was determined that the most important factor causing stress was found by business conditions.
\end{abstract}

Key Words: Stress, Work stress, Factor analysis, ANOVA, Structural equation model, Administrative staff

Atıf İçin / Please Cite As:

Gürbüz, H. (2020). İş stresi ve Eskişehir Osmangazi Üniversitesi idari personel üzerine bir araştırma. Manas Sosyal Araștırmalar Dergisi, 9(3), 1716-1730.

Geliş Tarihi / Received Date: 24.06.2019

Kabul Tarihi / Accepted Date: 16.04.2020

\footnotetext{
${ }^{1}$ Doç. Dr. - Eskişehir Osmangazi Üniversitesi, İktisadi Ve İdari Bilimler Fakültesi İşletme Bölümü, hgurbuz@ogu.edu.tr ORCID:0000-0002-1085-9164
} 


\section{Giriş}

Günümüzde giderek yaygınlaşan, insanların ve örgütlerin varllğını, performansını olumsuz yönde etkileyen stres çağımızın hastalığı olarak nitelenmektedir. Buna rağmen stresin kaynakları ve etkileri bireyler ve örgütler tarafindan bilimsel anlamda yeterince bilinmemektedir. Stres nedeniyle oluşan sorunlar, genellikle o anki duruma göre yüzeysel olarak çözülmekte ve nedenleri araştırılmamaktadır. Bu nedenle, aynı ya da benzer sorunları, aynı örgütte değişik zamanlarda değişik bireyler tekrar yaşayabilmektedir.

Stres günümüzde, yaşantımızın doğal bir parçası haline gelmiştir. İnsanlar hangi sektörde çalışırsa çalıssın (kamu, özel ya da serbest) yaşamlarının büyük bir bölümünde yeteneklerini ve sınırlarını zorlayarak sürdürdüklerinden stres kavramıyla tanışması kaçınılmaz olmaktadır (Arıcan, 2011, s. 56).

Her sektörün verimli olabilmesi için, çalışanların bireysel kapasitesini mümkün olan en üst düzeye çıkarmasıyla gerçekleşir. Çalışanlar yaptıklanı işten veya iş ortamından memnun olduklanı, çalışma ortamındaki stresin minimum olduğu ölçüde bireysel motivasyonları artar ve dolayısıyla çalışmalarında verimli olurlar. Kamu kurum ve kuruluşlarında özel sektöre kıyasla insan sermayesinden en üst düzeyde yararlanıldığını söylemek zordur. Kamu sektöründe çalışanlarda özel sektöre göre işten çıkarılma korkusu, günlük işlerini yetiştirme gibi iş stresinin bir parçası olan etkenlerinin daha az olduğu söylenebilir (Gürbüz vd., 2014, s. 113-114).

Kamu kurum veya kuruluşlarında görev yapan memurların yaptıkları işin ağırllğı altında ezilmesi memurların stres seviyesini yükseltmektedir. Kamu ve/veya özel sektörde içerisinde verim sağlayabilmenin başında nitelikli personele sahip olmanın yanında kurumda çalışanların çalışmaya istekli olması gelir. Çalışma istekliliğ̣i ise bireyin kendisinden kaynaklandığı gibi yönetimin çalışanını nasıl güdelediğine de bağlıdır. Yönetimin desteği ile çalışanın istekliliği ve motivasyonu, dolayısıyla başarısı en üst düzeye çıkartılabilir. Yönetimin desteğini alan çalışanların, problemleri çözmede ve başarıya odaklanmakta daha istekli olacakları kabul edilmektedir. Kurumun çalışana sunduğu olanaklar çalışanın yeteneklerini kullanmada önemli belirleyicilerdir (Karakaya ve Ay, 2007, s. 57). Bu durumun çalışan tarafindan bilinmesi de kişideki iş ortamı stresini bir ölçüde ortadan kaldırabilmektedir.

\section{Stres Kavramı}

Latince estrictia, Fransizca'da estrece kelimesinden gelen stres, 17. yüzyllda felaket, bela, dert, keder, elem, 18 ve 19. yüzylllarda ise güç, baskı, zor gibi anlamlarda objelere, kişiye, organlara ve ruhsal yapıya yönelik olarak kullanılmıştır. Dolayısıyla stres, nesne ve kişinin bu tür güçlerin etkisi ile biçiminin bozulmasına karşı bir direnç anlamında kullanılmaya başlamıştır (Güçlü, 2001, s. 92; Baltaş ve Baltaş, 1998, s. 298; Aydın, 2008, s. 1-2).

Fransız fizyoloğu Claude Bernard stresi, organizmanın dengesini bozan uyaranlar olarak tanımlamıştır (Keser, 2009, s. 49; Karasakal ve Yücebalkan, 2017, s. 375). Selye, stresi vücuda yüklenilen herhangi bir özel olamayan isteme karşı, vücudun tepkisi (Selye, 1956, s. 54; Johnstone, 1989, s. 4) veya bireye yapılan etkilere özel olmayan tepki olarak tanımlamaktadır (Selye, 1974, s. 11; Güler vd., 2001, s. 2). Selye, stresi bireyin çevresel stresörlere karşı gösterdiği genel tepki olarak tanımlanmışır (C a m, 2004 , s.2). Stres, bireyin karakterini içeren ve birey-çevre arasındaki ilişsi ve çevresel olayların birey üzerinde oluşturduğu etkidir (Lazarus ve Folkman, 1984, s. 21; Göksel ve Tomruk, 2016, s. 319). Cüceloğlu ise stresi bireyin fiziki ve sosyal çevredeki uygun olmayan koşullar nedeniyle, fiziksel ve ruhsal olarak sınırlarının üzerinde harcadığı çaba şeklinde tarif etmektedir (Cüceloğlu, 1994, s. 321; Güçlü, 2001, s. 92).

Stres, birey ve çevre arasındaki etkileşim sonucunda oluşur. Streste dikkate alınması gereken bir tehlike söz konusudur. Stres, kısıtlama, firsat, istek ve beklentilerle ilgilidir. Stres bireyin çalıştı̆ı örgütün tümünü etkiler (Aydın, 2004, s. 52-54; Tutar vd., 2006, s. 189; Soysal, 2009, s. 19). Stres çalışanların davranışlarını, performanslarını ve diğer kurum çalışanlarıyla ilişkilerini etkilemektedir (Ceylan ve Ulutürk, 2006, s. 48; Karakaş ve Gökmen, 2017, s. 104).

\section{İş Stresi}

Stres, iş yaşamında önemli bir etkiye sahiptir. İş yaşamında stres; hem iş görenlerin ve hem de işverenlerin veriminde düşme, işe olan odaklanma oranındaki azalma gibi sonuçlar doğuran bir olgu ve bazı yazarlara göre de hastalık olarak tanımlanmaktadır. Dolayısıyla stres, sonuçları itibariyle çözülmesi gereken bir sorun olarak, iş yaşamındaki bireyleri olumsuz yönde etkilemektedir (Çam, 2004, s. 2). 
İş stresi çalışanların iş yerinde karşılaştıklanı ve onları fizyolojik, psikolojik ve zihinsel olarak etkileyen, iş yerinin hedeflerine ulaşma noktasında olumlu ya da olumsuz sonuçları bulunan durumdur (Yüksel, 2014, s. 116). İş stresi, çalışan ve çevresi arasındaki etkileşim sonucu oluşan gerilim ve olumsuz psikolojik durum olarak tanımlanmaktadır (Yenihan vd., 2014, s. 39). İş stresi, çalışanların gündelik işlerini yapmasına engel olan ya da verimini azaltan davranışlar sergilemesine neden olan bir psikolojik durumdur. İş stresi çalışanların normal işlevlerini yerine getirmesini engellemekte ve dolayısıyla bireyin fiziksel ve zihinsel olarak tepki göstermesine neden olmaktadır (Gül, 2007, s. 319; Tekin, 2010, s. 33).

Örgütsel stres olarak da tanımlanan iş stresi, bireylerin normal işlevlerinden farklılaşmaya zorlayan değişmeler karşısında, onların işleriyle ve diğer insanlarla etkileşiminden kaynaklanan durumdur (Pehlivan, 1992, s. 792; Serinkan, vd., 2012, s. 23). İş yerinde çalışan bireylerin rol belirsizliği-rol çatışmasının; çalışanın performansını, verimliliğini ve iş memnuniyetini azalttığını bu durum sonucunda ise bireylerde tükenmişlik, tatminsizlik, kazalar, işten ayrılma isteği ve hastalıkların arttığı görülmektedir (Köse, 2015). İşverenin çalışan bireylerden beklediği verimlilik artışı, bireyin iş yerindeki istihdamını sürdürebilmek ve beklentilere karşlık verme çabaları, birey üzerinde strese yol açmaktadır (Yürür ve Keser, 2011, s. 169).

\section{İş Stresinin Kaynakları}

İş stresine yol açan faktörler bilim adamları tarafindan çok farklı şekilde sıralanmaktadır. İş yeri stresinin en önemli kaynaklarından başında rol belirsizliği ve rol çatışmasından gelmektedir Rol çatışması, farklı kaynaklardan birden çok talebin gelmesi sonucunda oluşmaktadır. Rol belirsizliği ise, örgütün çalışana rolü ile ilgili sınırlarını tam olarak bildirmemesi sonucu ortaya çıkmaktadır (Gül, 2007, s. 320). İş stresi; örgütün yapısında ve iş kolundan, bireyin kendinden kaynaklanan stres, davranış ortamından kaynaklanan stres, iş ortamındaki fiziksel ve sosyal çevreden kaynaklanan stres ve role bağlı strestir (Soysal, 2009, s. 20).

İş yerindeki stres kaynakları; iş yükünün fazlalığı, işin bitirilme zamanın kısıtlllığı, denetimin niteliğinin düşük olması, yetkinin sorumlulukları karşılamada yetersiz kalması, politik havanın güvensizliği, rol belirsizliği, rol çatışması, rol ile ilgili aşırı yük, örgüt ve bireyin değerleri arasında uyumsuzluk, birey ile işi arasında uyumsuzluk, çalışma koşulları, birey ile çalışma arkadaşları arasındaki sorunlu ilişkilerdir (Davis ve Newstrom, 1988, s. 422; Yıldız ve Güneş, 2017, s. 49). İş hayatında birçok faktörün stres kaynağı olarak değerlendirilmesi mümkün olduğundan, örgütsel stres kaynaklarının pek çok sınıflandırmasının yapıldığ1 görülmüştür. Tablo 1'de iki farklı çalışmadan oluşturulan örgütsel stres kaynaklarına yer verilmiştir (Gökdeniz, 2005, s. 178; Ergül, 2012, s. 531-532; Tekin, 2010, s. 49; Akgündüz, 2006, s. 51-52).

Tablo 1. Örgütsel Stres Kaynaklarmmn Karşılaştırılması

\begin{tabular}{|c|c|}
\hline Örgütsel Stres Kaynakları & Örgütsel Stres Kaynakları \\
\hline 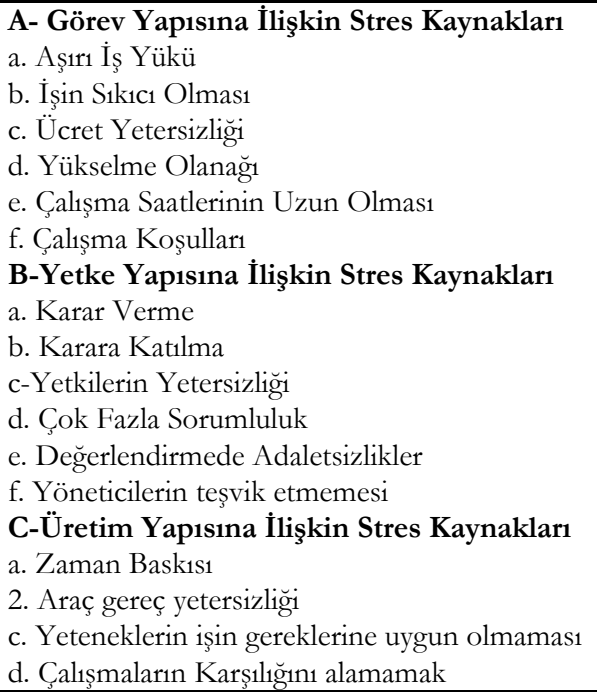 & $\begin{array}{l}\text { A-İşin Gereklerinden Kaynaklanan Stres Kaynakları } \\
\text { a. Bıkkınlık } \\
\text { b. Kötü Çalışma } \\
\text { Koşulları(Çevresel S K) } \\
\text { c. Zaman kısıtlaması } \\
\text { d. Aşırı İş̧ Yükü } \\
\text { e. Aşırı Bilgi Yükü } \\
\text { f. İş Tasarımı ve teknik sorunlar } \\
\text { B-Örgütsel Rolden Kaynaklanan Stres Yapıcılar } \\
\text { a. Rol Çatışması } \\
\text { b. Rol Belirsizliği } \\
\text { c. İnsanlardan Sorumlu olma } \\
\text { d. Örgüt alanı } \\
\text { C-Mesleki Gelişimden Kaynaklanan Stres Yapıcılar } \\
\text { a. Yeterince İlerleyememe } \\
\text { b. Aşırı İlerleme } \\
\text { c. İş Güvenliğinin Eksikliği } \\
\text { d. Engellenmiş Hırslar } \\
\text { e. Başarı }\end{array}$ \\
\hline
\end{tabular}


Tablo 1 - Devamı

\begin{tabular}{|c|c|}
\hline Örgütsel Stres Kaynakları & Örgütsel Stres Kaynakları \\
\hline $\begin{array}{l}\text { D-Toplumsal Çevre ve Stres Kaynakları } \\
\text { E-Kümeleşme Yapısına İlişkin Stres Kaynakları / } \\
\text { Örgütsel Yapı ve İklime İlişkin Stres Kaynakları } \\
\text { a. Isş Ortamında Huzursuzluk } \\
\text { b. Ast-Üst ve İş Arkadaşları İle Anlaşmazlık } \\
\text { c. Toplumsal Desteğin Düzeyi } \\
\text { d. İşyerinde Dedikodu Yapılması } \\
\text { F-Rol Yapısına İlişkin Stres Kaynakları } \\
\text { a. Rol Çatışması } \\
\text { b. İş Gerekleri İle Kişilik Uyumsuzluğu } \\
\text { c. Rol Belirsizliği } \\
\text { G-Kültürel Yapıya İlişkin Stres Kaynakları } \\
\text { a. İş Ortamında Görüş Farklıllıları } \\
\text { b. Statü Düşüklüğü } \\
\text { c. İs Cevresindeki Ortak Değer ve Normlara Uyum }\end{array}$ & $\begin{array}{l}\text { D-İşteki İliş̧kilerden Kaynaklanan Stres Yapıcılar } \\
\text { a. Astlarla İlişkiler } \\
\text { b. Üstlerle ilişkiler } \\
\text { c. Meslektaşlarla İlişkiler } \\
\text { E-Örgüt yapısı ve İkliminden kaynaklanan Stres Yapıcılar } \\
\text { a. Katılmanın olmayışı } \\
\text { b. Bürokratik sorunlar } \\
\text { c. Uyum baskısı }\end{array}$ \\
\hline
\end{tabular}

Kaynak: Pehlivan, İ. (1995), Yönetimde Stres Kaynakları, Personel Geliştirme Merkezi Yayınları, Ankara. s. 15-43; Artan, İ. (1986). Örgütsel Davranış, Örgütsel Stres Kaynakları ve Yöneticiler Üzerinde Bir Uygulama, Basisen Eğitim ve Kültür Yayınları, İstanbul. s. 67-103.

\section{Yöntem}

\section{Araştırmanın Amacı ve Önemi}

Bu çalışmanın amac1; bir kamu kurumu olan Eskişehir Osmangazi Üniversitesi idari personeline uygulanan anket aracıllyla iş stresi düzeylerini belirlemektir. Literatürde iş stresi üzerine yapılan çalışmalar incelendiğinde genellikle banka çalşanlanı, emniyet personeli, askeri personel, sağlık sektörü personeli, muhasebe meslek çalışanları, otel işletmelerinde çalışan personel ve yöneticileri gibi daha çok strese maruz kalan kurumlarda çalışanlara uygulandığı görülmektedir. Çalışanın iş yerinde yaşadığı stres, çalışanın sadece iş yaşamındaki performansını ve iş arkadaşlarıyla olan ilişkilerinin değil, aynı zamanda aile yaşamını da etkileyecektir. Bu nedenle çalışanların sahip oldu iş stresinin nedenleri ve bu stresi meydana getiren sorunların çözümü çok önemlidir.

\section{Araştırma Yöntemi}

Araştırmanın evreni Eskişehir Osmangazi Üniversitesi’nde 657 Sayılı Devlet Memurları Kanunu'na tabii çalışan 1567 idari personel oluşturmaktadır. Çalışma 1-25 Haziran 2017 yllında, basit tesadüfi örnekleme yöntemine göre örneklemeye seçilen İ̈BF, Mühendislik Fak., Fen-Ed. Fak ve Rektörlük idari personeline anket formu dağıtılarak 160 anket değerlendirmeye alınmıstır.

Örnek hacmi, \%95 güven aralığ1 ve \%7 hata payı ile 174 olarak hesaplanmıştır (https://www.surveysystem.com/sscalc.htm). Toplamda 220 idari personele uygulanan anketlerden 190 geri dönüş sağlanmış, hatalı ve eksik anketler değerlendirmeye alınmamıştır. Anket geri dönüşüm oranı $\% 86$ 'dir.

Anket formu iki bölümden oluşmaktadır. Birinci bölümde demografik özelliklerle ilgili 7 adet soru yer almaktadır. Anketin ikinci bölümünde stres kaynaklarına ilisskin 16 adet sorudan oluşmaktadır.

Anketin ikinci bölümündeki stres kaynaklarına ilişkin sorular "Healtby Island Resorts-Queens and Government Tropical Public Health Unit Network December 2001" tarihli sayısinda yer alan "Stress at Work" araştırmasında uygulanan anket formundan yararlanılmıştır (Queeensland Healt, 2001: 1). Anketteki sorular uzmanlar tarafindan Türkçeye ve tekrar İngilizceye çevrilerek test edilmiştir. 50 örnekleme uygulanan pilot çalışma sonucunda Cronbach Alpha değeri \%76 bulunmuştur.

Ankette stresle ilgili önermelere verilecek cevaplar için 5'li Likert Ölçeği kullanılmıştır (1: Asla, 2: Nadiren, 3: Bazen, 4:Genellikle, 5: Her zaman). Araştırmaya katılanlardan, kendilerine en uygun gelen seçeneği doldurmaları istenmiştir. Araştırma sonucunda elde edilen veriler SPSS ve Lisrel programları kullanılarak analiz edilmiştir. Araştırmada elde edilen verilerin frekansları yorumlanmış ve faktör analizi sonucunda elde edilen faktörlerle demografik özellikler arasındaki anlamlı bir farklılık olup olmadığ t-testi ve F- testiyle (varyans analizi) incelenmiştir. Ayrıca faktör analizi sonucu elde edilen bulgular yapısal eşitlik modeliyle (YEM) test edilmiştir. 


\section{Bulgular}

Kişisel Bilgiler ve stresin çalışanlar üzerine etkisini ölçmeye yönelik uygulanan anket formundan elde edilen veriler şu şekilde özetlenebilir. Anket formunun uygulandığı 160 kişinin 82'si kadın(\%51,2), 78’i erkektir( 48,8$)$. Aşağıdaki tablodan da anlaşılacağı üzere çalışanların \%50,7'lik oranla 35-45(58 kişi) yaş arası ile 45 yaş ve üzeri (23 kişi) olması nedeniyle daha çok orta yaştaki kişilerden oluşmaktadır. Lisans mezunu 92, lisansüstü eğitim yani yüksek lisans ve doktora mezunu 24 kişi bulunmakta olup ankete katılan idari personelin eğitim seviyesinin yüksek olduğu görülmektedir. Toplam çalısma sürelerine bakıldı̆̆ında 58 kişinin 10-20 yıl arası 26 kişinin 20 yıl ve üzeri olduğu ve deneyimlerinin fazla olduğu anlaşılmaktadır. Kurumda çalışma sürelerine bakıldığında 15 kişinin 1 yıldan az, 68 kişinin 1-5 yll arası olduğu toplam çalışma süreleri ile kıyaslandığında daha önce başka bir kurumda çalıştıktan sonra üniversiteye geçtikleri anlaşılmaktadır. Aşağıdaki tablolarda Eskişehir Osmangazi Üniversitesinde çalışan idari personelin demografik özelliklerinin frekans ve yüzdeleri tablo 2'de, ifadelere verdikleri cevapların frekans, yüzde ve ortalamaları ise tablo 3'de verilmiştir.

Tablo 2. Eskişehir Osmangazi Üniversitesinde Calısan İdari Personelin Demografik Özellikleri

\begin{tabular}{|c|c|c|c|}
\hline Demografik özellikler & & $\mathrm{N}$ & Yüzde $(\%)$ \\
\hline \multirow{2}{*}{ Cinsiyet } & Kadin & 82 & 51,2 \\
\hline & Erkek & 78 & 48,8 \\
\hline \multirow{2}{*}{ Medeni durum } & Bekâr & 57 & 35,6 \\
\hline & Evli & 103 & 64,4 \\
\hline \multirow{5}{*}{ Yaş } & $25^{\prime}$ den az & 8 & 5 \\
\hline & $25-30$ yaş & 43 & 26,9 \\
\hline & $30-35$ yaş & 28 & 17,5 \\
\hline & $35-45$ yaş & 58 & 36,3 \\
\hline & 45 yaş ve üzeri & 23 & 14,4 \\
\hline \multirow{4}{*}{ Öğrenim durumu } & Orta öğretim & 20 & 12,5 \\
\hline & Önlisans & 24 & 15 \\
\hline & Lisans & 92 & 57,5 \\
\hline & Yüksek l. /doktora & 24 & 15 \\
\hline \multirow{5}{*}{ Toplam çalışma süresi } & 1 yildan az & 8 & 5 \\
\hline & $1-5 \mathrm{yil}$ & 49 & 30,6 \\
\hline & $5-10 \mathrm{y} 1 \mathrm{l}$ & 19 & 11,9 \\
\hline & $10-20 \mathrm{y} 1 \mathrm{l}$ & 58 & 36,3 \\
\hline & 20 yll ve üzeri & 26 & 16,3 \\
\hline \multirow{5}{*}{ Kurumda toplam çalışma süresi } & 1 yildan az & 15 & 9,4 \\
\hline & $1-5 \mathrm{yll}$ & 68 & 42,5 \\
\hline & $5-10 \mathrm{y} 1 \mathrm{l}$ & 23 & 14,4 \\
\hline & $10-20 \mathrm{y} 1 \mathrm{l}$ & 42 & 26,3 \\
\hline & 20 yll ve üzeri & 12 & 7,5 \\
\hline \multirow{5}{*}{ Aylık geliriniz } & 1500 TL'den az & 9 & 5,6 \\
\hline & $1500-2000 \mathrm{TL}$ & 76 & 47,5 \\
\hline & 2000-3000 TL & 65 & 40,6 \\
\hline & $3000-4000 \mathrm{TL}$ & 7 & 4,4 \\
\hline & 4000 TL ve üzeri & 3 & 1,9 \\
\hline \multirow{4}{*}{ Unvanınız } & Müdür & 9 & 5,6 \\
\hline & Şef & 19 & 11,9 \\
\hline & Memur & 124 & 77,5 \\
\hline & Teknik & 8 & 5 \\
\hline
\end{tabular}


Tablo 3. Eskişehir Osmangaz̧ Üniversitesinde Cahșan İdari Personel Tarafindan Iffadelere Verilen Cevaplar

\begin{tabular}{|c|c|c|c|c|c|c|c|c|c|c|c|}
\hline \multirow[b]{2}{*}{ İfadeler } & \multicolumn{2}{|c|}{$\begin{array}{c}\text { Her } \\
\text { zaman }\end{array}$} & \multicolumn{2}{|c|}{ Genellikle } & \multicolumn{2}{|c|}{ Bazen } & \multicolumn{2}{|c|}{ Nadiren } & \multicolumn{2}{|c|}{ Asla } & \multirow[b]{2}{*}{ Ortalama } \\
\hline & $\mathrm{f}$ & $\%$ & $\mathrm{f}$ & $\%$ & $\mathrm{f}$ & $\%$ & $\mathrm{f}$ & $\%$ & f & $\%$ & \\
\hline Her gün, işe gitmek için can atıyorum. & 8 & 5 & 23 & 14,4 & 60 & 37,5 & 42 & 26,3 & 27 & 16,9 & 2,6438 \\
\hline $\begin{array}{l}\text { İşimi kendimi geliştirmem konusunda } \\
\text { yeterli buluyorum. }\end{array}$ & 10 & 6,3 & 73 & 45,6 & 31 & 19,4 & 25 & 15,6 & 21 & 13,1 & 3,1625 \\
\hline $\begin{array}{l}\text { İssimde etkili ve yararlı olabileceğim } \\
\text { konusunda kendime güveniyorum. }\end{array}$ & 42 & 26,3 & 93 & 58,1 & 14 & 8,8 & 8 & 5 & 3 & 1,9 & 4,0188 \\
\hline $\begin{array}{l}\text { İşyerinde benden ne beklendiğinin } \\
\text { farkındayım. }\end{array}$ & 47 & 29,4 & 68 & 42,5 & 16 & 10 & 19 & 11,9 & 10 & 6,3 & 3,7688 \\
\hline İşimde kendimi güvende hissediyorum. & 22 & 13,8 & 78 & 48,8 & 25 & 15,6 & 24 & 15 & 11 & 6,9 & 3,4750 \\
\hline İş hayatımda gelecek kaygısı yaşıyorum. & 25 & 15,6 & 43 & 26,9 & 54 & 33,8 & 26 & 16,3 & 12 & 7,5 & 3,2688 \\
\hline İş arkadaşlarımla çalışmaktan keyif & 43 & 26,9 & 50 & 31,3 & 44 & 27,5 & 14 & 8,8 & 9 & 5,6 & 3,6500 \\
\hline $\begin{array}{l}\text { İş nedeniyle görüştüğüm insanlara ilgi } \\
\text { gösteririm. }\end{array}$ & 53 & 33,1 & 61 & 38,1 & 36 & 22,5 & 7 & 4,4 & 3 & 1,9 & 3,9625 \\
\hline $\begin{array}{l}\text { İşyerinde sorunlar meydana geldiğinde, } \\
\text { bunları yapıcı bir şekilde çözebileceğime } \\
\text { inanıorum. }\end{array}$ & 49 & 30,6 & 61 & 38,1 & 33 & 20,6 & 12 & 7,5 & 5 & 3,1 & 3,8563 \\
\hline $\begin{array}{l}\text { İşyerinde etkili bir destek ve denetim ağına } \\
\text { sahibim. }\end{array}$ & 6 & 3,8 & 62 & 38,8 & 42 & 26,3 & 39 & 24,4 & 11 & 6,9 & 3,0813 \\
\hline $\begin{array}{l}\text { Hizmet içi eğitim programlarına katılmada } \\
\text { arkadaşlarımla eşit şansa sahibim. }\end{array}$ & 11 & 6,9 & 44 & 27,5 & 24 & 15,0 & 46 & 28,8 & 35 & 21,9 & 2,6875 \\
\hline $\begin{array}{l}\text { Yöneticilerim, iş hayatımın yanında özel } \\
\text { hayatımın da olduğunun farkında. }\end{array}$ & 34 & 21,3 & 49 & 30,6 & 35 & 21,9 & 21 & 13,1 & 21 & 13,1 & 3,3375 \\
\hline İş arkadaşlarım işimde beni destekler. & 38 & 23,8 & 69 & 43,1 & 32 & 20 & 14 & 8,8 & 7 & 4,4 & 3,7313 \\
\hline İş günü sonunda yeterli enerjim kalmıyor & 10 & 6,3 & 39 & 24,4 & 48 & 30 & 44 & 27,5 & 19 & 11,9 & 2,8563 \\
\hline $\begin{array}{l}\text { İş ve özel hayatımdaki sorumluluklar } \\
\text { dengelidir. }\end{array}$ & 35 & 21,9 & 65 & 40,6 & 35 & 21,9 & 17 & 10,6 & 7 & 4,4 & 3,6625 \\
\hline $\begin{array}{l}\text { Ailem ve iş hayatım dışında kendime } \\
\text { yeterli vakit ayırıyorum. }\end{array}$ & 12 & 7,5 & 55 & 34,4 & 31 & 19,4 & 47 & 29,4 & 15 & 9,4 & 3,0125 \\
\hline
\end{tabular}

Tablo 3'de ifadelere verilen yanitların ortalamaları sırasıly 1-1,80: Asla; 180-2,60: Nadiren, 2,603,40:Bazen; 3,40-4,20:Genellikle; 4,20-5,00:Herzaman şıklarına karş1l1k gelmektedir.

Tablo 3'de ifadelerin ortalamaları incelendiğinde en yüksek ortalamanın 4,0188 ile 'İşimde etkili ve yararlı olabileceğim konusunda kendime güveniyorum' olduğu ve bunu sırasıyla 3,9625 ve diğerlerinin izlediği görülmektedir. Katılımcılar ifadelerin \%50'sine genellikle katıldıklarını, \%50'sine ise bazen katıldıklarını belirtmişlerdir. İfadeler arasından en düşük ortalama ise 2,6438 ile 'Her gün, işe gitmek için can atyorum'dur.

Birbirleri ile ilişkili veri yapılarını birbirinden bağımsız ve daha az sayıda yeni veri yapılarına dönüştürmek için araştırmada faktör analizi yapılmıştır.

\section{Faktör Analizi Sonuçları}

Veri setinin faktör analizine uygun olup olmadığını belirlemek için Barlett testi ve Kaiser-MeyerOlkin(KMO) testi kullanılmıştır. Barlett testinin sonucu 995,212 ve p:0,001; KMO ise 0,754'dur. Barlett ve KMO testlerinin sonucuna göre veri seti faktör analizi için uygundur. Faktör sayısını belirlemede özdeğer istatistiği ile isimlendirilebilir ve yorumlanabilir faktörler elde etmek için ise varimax rotasyonu kullanılmıştır (Kalayc1 v.d., 2006, s. 322).

Aşağıdaki tablolardan da anlaşılacağı üzere uygulanan faktör analizi sonucunda 16 ifade 4 faktör altında toplanmıştır. Her faktörde iki ve daha fazla ifade olması nedeniyle gruplanamayan ifade olmamıştır. 
Tablo 4. Faktör Analiz̨i Sonuclar

\begin{tabular}{|c|c|c|c|}
\hline Faktörler & $\begin{array}{c}\text { Faktör } \\
\text { Yükleri } \\
\end{array}$ & $\begin{array}{c}\text { Aç1klanan } \\
\text { Varyans \% }\end{array}$ & $\begin{array}{c}\text { Cronbach } \\
\text { Alpha }\end{array}$ \\
\hline Faktör 1-İş Koşulları & 5,233 & 32,705 & 0,714 \\
\hline \multirow{5}{*}{$\begin{array}{l}\text { S10-İşyerinde Etkili Bir Destek Ve Denetim Ağına Sahibim. } \\
\text { S11-Hizmet İçi Eğitim Programlarına Katılmada Arkadaşlarımla Eşit Şansa } \\
\text { Sahibim. } \\
\text { S6-İs Hayatımda Gelecek Kaygısı Yaşıyorum. } \\
\text { S14-İş Günü Sonunda Yeterli Enerim Kalmıor. } \\
\text { S1-Her Gün, İșe Gitmek İçin Can Atıyorum. }\end{array}$} & 0,705 & & \\
\hline & 0,673 & & \\
\hline & 0,644 & & \\
\hline & 0,428 & & \\
\hline & 0,406 & & \\
\hline \multirow{5}{*}{$\begin{array}{l}\text { Faktör 2-Sorumluluklar } \\
\text { S4-İșyerinde Benden Ne Beklendiğinin Farkındayım. } \\
\text { S15-İş Ve Özel Hayatımdaki Sorumluluklar Dengelidir. } \\
\text { S3-İssimde Etkili Ve Yararlı Olabileceğim Konusunda Kendime Güveniyorum. } \\
\text { S2-İssimi Kendimi Geliştirmem Konusunda Yeterli Buluyorum. }\end{array}$} & 1,912 & 11,95 & 0,725 \\
\hline & 0,76 & & \\
\hline & 0,729 & & \\
\hline & 0,678 & & \\
\hline & 0,583 & & \\
\hline Faktör 3-İş Arkadaşları & 1,42 & 8,875 & 0,776 \\
\hline \multirow{5}{*}{$\begin{array}{l}\text { S7-İş Arkadaşlarımla Çalışmaktan Keyif Alıyorum. } \\
\text { S16-Ailem Ve İş Hayatım Dışında Kendime Yeterli Vakit Ayırıyorum. } \\
\text { S12-Yöneticilerim, İş Hayatımın Yanında Özel Hayatımın Da Olduğunun } \\
\text { Farkında. } \\
\text { S13-İş Arkadaşlarım İşimde Beni Destekler. } \\
\text { S5-İșimde Kendimi Güvende Hissediyorum. }\end{array}$} & 0,7 & & \\
\hline & 0,653 & & \\
\hline & 0,612 & & \\
\hline & 0,604 & & \\
\hline & 0,59 & & \\
\hline Faktör 4-İletişim & 1,187 & 7,416 & 0,748 \\
\hline \multirow{2}{*}{$\begin{array}{l}\text { S8-İş Nedeniyle Görüştüğüüm İnsanlara İlgi Gösteririm. } \\
\text { S9-İsyerinde Sorunlar Meydana Geldiğinde, Bunları Yapıcı Bir Şekilde } \\
\text { Çözebileceğime İnanıyorum. }\end{array}$} & 0,813 & & \\
\hline & 0,811 & & \\
\hline \multicolumn{2}{|l|}{ Kümülatif varyans: $\% 60,946$} & & \\
\hline
\end{tabular}

Uygulanan ankette 16 ifade için güvenilirlik analizi yapılarak cronbach alfa değeri \% 86 olarak belirlenmiştir. Tablo 4'de görüleceği üzere elde edilen faktörlerin güvenilirlik düzeyleri 0,714 - 0,776 arasında değer almakta ve güvenilirlik düzeyinin iyi olduğu anlaşılmaktadır. Ayrıca araştırmada 1. faktör varyansın \%32,75’ini, 2. faktör \%11,95’ini, 3. faktör 8,875'ini, 4. faktör \%7,416’inı açılamaktadır.

\section{Tek Yönlü Varyans Analizi}

Cinsiyet ve medeni durumla, faktörler arasında anlamlı bir farklılı̆̆ın olup olmadığı t testi ile araştırılmış ve testin sonucunda her iki değişken içinde istatistiksel açıdan anlamlı bir farklılık bulunamamıştır. Yaş, eğitim durumu, toplam çalışma süresi, kurumdaki çalışma süresi, aylık gelir ve ünvanları gibi ikiden fazla grubun faktörlerle karşılaştırılması amacıyla tek yönlü varyans analizi (Anova) kullanılmıştır. Eskişehir Osmangazi Üniversitesi idari personelin çalışanların yaşlarıyla stres boyutlarının varyans analizleri sonuçları Tablo 5'de gösterilmiştir.

Tablo 5. Eskişehir Osmangazi Üniversitesinde Calışan İdari Personelin Yaşlarna Göre Stres Boyutlarmmn Varyans Analizi Sonuclar

\begin{tabular}{|c|c|c|c|c|c|c|}
\hline & & Kareler Toplamı & sd. & Kareler Ortalaması & $\mathbf{F}$ & $\mathbf{P}$ \\
\hline \multirow{3}{*}{ İş Koşulları } & Gruplar Aras1 & 19,706 & 4 & 4,926 & 5,482 & 0,001 \\
\hline & Gruplar İçi & 139,294 & 155 & 0,899 & & \\
\hline & Toplam & 159,000 & 159 & & & \\
\hline \multirow{3}{*}{ Sorumluluklar } & Gruplar Aras1 & 9,109 & 4 & 2,255 & 2,330 & 0,058 \\
\hline & Gruplar İçi & 149,981 & 155 & 0,968 & & \\
\hline & Toplam & 159,000 & 159 & & & \\
\hline \multirow{3}{*}{ İş Arkadaşları } & Gruplar Arası & 8,478 & 4 & 2,120 & 2,183 & 0,073 \\
\hline & Gruplar içi & 150,522 & 155 & 0,971 & & \\
\hline & Toplam & 159,000 & 159 & & & \\
\hline \multirow{3}{*}{ İletişim } & Gruplar arası & 8,660 & 4 & 2,165 & 2,232 & 0,068 \\
\hline & Gruplar içi & 150,340 & 155 & 0,970 & & \\
\hline & Toplam & 159,000 & 159 & & & \\
\hline
\end{tabular}

Varyans analizi sonucunda sorumluluklar $(p=0,058)$, iş arkadaşları $(p=0,073)$, iletişim $(p=0,068)$ stres boyutlarıyla, idari personelin yaşları karşılaştırılmış $\mathrm{p}<0,05$ değeri sağlanamadığından anlamlı bir fark bulunamamıştır. İş koşulları $(\mathrm{F}=5,482, \mathrm{p}=0,001<0,05)$, stres boyutu ile idari personelin yaşları arasındaki ise anlamlı bir fark olduğu anlaşılmıştır. 
$\mathrm{Bu}$ farklılığın hangi yaș grubundan kaynaklandığının araştırılmasında, grupların varyanslarının homojen olmaması nedeniyle Tamhane's T2 testiyle analiz edilmiştir. Analiz sonucunda 45 ve üzeri yaş1 olan idari personelinin iş koşulları stres boyutunun daha fazla olduğu anlaşılmıştır.

Eskişehir Osmangazi Üniversitesi idari personelinin eğitimleriyle stres boyutlarının varyans analizleri sonuçları Tablo 6'da verilmiştir.

Tablo 6. Eskişehir Osmangaẓ Üniversitesinde Çalşan İdari Personelin Eğitimlerine Göre Stres Boyutlarmm Varyans Analizi Sonuclar

\begin{tabular}{|c|c|c|c|c|c|c|}
\hline & & Kareler Toplamı & Sd. & Kareler Ortalaması & F & $\mathbf{P}$ \\
\hline \multirow{3}{*}{ İş Koşulları } & Gruplar Aras1 & 3,309 & 3 & 1,103 & 1,105 & 0,349 \\
\hline & Gruplar İçi & 155,691 & 156 & 0,998 & & \\
\hline & Toplam & 159,000 & 159 & & & \\
\hline \multirow{3}{*}{ Sorumluluklar } & Gruplar Aras1 & 0,830 & 3 & 0,277 & 0,273 & 0,845 \\
\hline & Gruplar İçi & 158,170 & 156 & 1,014 & & \\
\hline & Toplam & 159,000 & 159 & & & \\
\hline \multirow{3}{*}{ İş Arkadaşları } & Gruplar Aras1 & 7,074 & 3 & 2,358 & 2,421 & 0,068 \\
\hline & Gruplar İçi & 151,926 & 156 & 9,974 & & \\
\hline & Toplam & 159,000 & 159 & & & \\
\hline \multirow{3}{*}{ İletişim } & Gruplar Aras1 & 8,803 & 3 & 2,934 & 3,048 & 0,030 \\
\hline & Gruplar İçi & 150,197 & 156 & 0,963 & & \\
\hline & Toplam & 159,000 & 159 & & & \\
\hline
\end{tabular}

Tablo G'ya göre iş koşulları $(\mathrm{p}=0,349)$, sorumluluklar $(\mathrm{p}=0,845)$, iş arkadaşları $(\mathrm{p}=0,068)$ stres boyutları ve idari personelin eğitimleriyle karşılaştırılması sonucunda $\mathrm{p}<0,05$ olduğundan anlamlı bir fark bulunamamıştır. İletişim $(\mathrm{F}=3,048, \mathrm{p}=0,030<0,05)$ stres boyutu ile idari personelin eğitimleri arasındaki karşılaştırmada ise anlamlı bir fark olduğu anlaşılmıştır. Yapılan post-hoc (Tamhane's T2) sınaması sonucunda, orta öğretim mezunlarının iletişim stres boyutunun daha fazla olduğu anlaşılmıştır.

Eskişehir Osmangazi Üniversitesi idari personelinin toplam çalışma süreleriyle stres boyutlarının varyans analizleri sonuçları Tablo 7'de verilmiştir.

Tablo 7. Eskişehir Osmangą̣i Üniversitesinde Calışan İdari Personelin Toplam Çallsma Sürelerine Göre Stres Boyutlarmin ANOV A Sonuclar

\begin{tabular}{|c|c|c|c|c|c|c|}
\hline & & Kareler & sd. & Kareler Ortalaması & $\mathbf{F}$ & $\mathbf{P}$ \\
\hline \multirow{3}{*}{ İş Koşulları } & Gruplar Arası & 29,048 & 4 & 7,262 & 8,662 & 0,001 \\
\hline & Gruplar İçi & 129,952 & 155 & 0,838 & & \\
\hline & Toplam & 159,000 & 159 & & & \\
\hline \multirow{3}{*}{ Sorumluluklar } & Gruplar Aras1 & 3,138 & 4 & 0,785 & 0,780 & 0,540 \\
\hline & Gruplar İçi & 155,862 & 155 & 1,006 & & \\
\hline & Toplam & 159,000 & 159 & & & \\
\hline \multirow{3}{*}{ İş Arkadaşları } & Gruplar Arası & 10,834 & 4 & 2,709 & 2,833 & 0,26 \\
\hline & Gruplar İçi & 148,166 & 155 & 0,956 & & \\
\hline & Toplam & 159,000 & 159 & & & \\
\hline \multirow{3}{*}{ İletişim } & Gruplar Arası & 13,546 & 4 & 3,387 & 3,609 & 0,008 \\
\hline & Gruplar İçi & 145,454 & 155 & 0,938 & & \\
\hline & Toplam & 159,000 & 159 & & & \\
\hline
\end{tabular}

Tablo 7'de incelendiğinde sorumluluklar $(\mathrm{p}=0,540)$ ve iş arkadaşları $(\mathrm{p}=0,26)$ stres boyutlarılya, idari personelin toplam çalışma sürelerinin karşılaştırılması sonucunda anlamlı bir fark bulunamamıştır $(\mathrm{p}<0,05)$. İș koşulları $(\mathrm{F}=8,662, \mathrm{p}=0,001<0,05)$ ve iletișim $(\mathrm{F}=3,609, \mathrm{p}=0,008<0,05)$ stres boyutları ile idari personelin toplam çalışma süreleri arasındaki karşılaştırmada ise anlamlı bir fark olduğu anlaşılmıştır.

İş koşulları ve idari personelin çalışma süreleri arasındaki farklılığın hangi gruptan kaynaklandığı belirlemek için (varyansların homojen olması nedeniyle) çoklu Tukey testi ile analiz yapılmış ve toplam çalışma süresi 1 yıldan az olan idari personelin iş koşulları stres boyutunun daha fazla olduğu anlaşılmıştır.

İletişim ve idari personelin çalışma süreleri arasındaki farklılığın hangi gruptan kaynaklandığı belirlemek için (varyansların homojen olmaması nedeniyle) Tamhane's T2 testiyle analiz yapılmış ve 
toplam çalışma süresi 1-5 yıl arasında olan idari personelin iletişim stres boyutunun daha fazla olduğu anlaşılmıştır.

Eskişehir Osmangazi Üniversitesi idari personelinin kurumda toplam çalışma süreleri ile stres boyutlarının varyans analizleri sonuçları ise Tablo 8'deki gibidir.

Tablo 8. Eskişehir Osmangazi Üniversitesinde Calısan İdari Personelin Kurumda Calısma Sürelerine Göre Stres Boyutlarmin ANOV A Sonuclar

\begin{tabular}{|c|c|c|c|c|c|c|}
\hline & & Kareler & sd. & Kareler Ortalaması & $\mathbf{F}$ & $\mathbf{P}$ \\
\hline \multirow{3}{*}{ İş Koşulları } & Gruplar Aras1 & 9,960 & 4 & 2,590 & 2,590 & 0,039 \\
\hline & Gruplar İçi & 149,040 & 155 & 0,962 & & \\
\hline & Toplam & 159,000 & 159 & & & \\
\hline \multirow{3}{*}{ Sorumluluklar } & Gruplar Arası & 2,252 & 4 & 0,563 & 0,557 & 0,694 \\
\hline & Gruplar İçi & 156,748 & 155 & 1,011 & & \\
\hline & Toplam & 159,000 & 159 & & & \\
\hline \multirow{3}{*}{ İş Arkadaşları } & Gruplar Aras1 & 12,196 & 4 & 3,049 & 3,219 & 0,014 \\
\hline & Gruplar İçi & 146,804 & 155 & 0,947 & & \\
\hline & Toplam & 159,000 & 159 & & & \\
\hline \multirow{3}{*}{ İletişim } & Gruplar Aras1 & 10,424 & 4 & 2,606 & 2,719 & 0,032 \\
\hline & Gruplar İçi & 148,576 & 155 & 0,959 & & \\
\hline & Toplam & 159,000 & 159 & & & \\
\hline
\end{tabular}

Tablo 8'de görüleceği üzere idari personelin kurumda çalışma süreleriyle, sorumluluk stres boyutu arasında $(\mathrm{F}=0,557 ; \mathrm{p}=0,694<0,05)$ istatistiksel açıdan anlamlı bir fark bulunamamıştır. İş koşullar1 $(\mathrm{F}=2,590 ; \mathrm{p}=0,039<0,05)$, iş arkadaşları $(\mathrm{F}=3,219 ; \mathrm{p}=0,014<0,05)$ ve iletişim $(\mathrm{F}=2,719 ; \mathrm{p}=0,032<0,05)$ stres boyutlarıyla, idari personelin kurumda çalışma süreleri arasında anlamlı bir fark olduğu anlaşılmıştır.

Post-hoc sınaması öncesinde yapılan homojenite testi sonucunda grupların varyanslarının homojen olmaması nedeniyle, Tamhane's T2 testiyle analiz yapılmış ve;

- Kurumda çalışma süresi 1-5 yıl olanların iş koşulları stres boyutunun 20 yıl ve üzeri olan idari personele göre az,

- Kurumda çalışma süresi 1 yıldan az olan idari personelin iş arkadaşlarıyla stres boyutunun diğer gruplara göre daha az,

- Kurumda çalışma süresi 1-5 y1l olanların, 5-10 yıl arası çalışma süresi olan idari personele göre iletişim stres boyutunun daha az olduğu anlaşılmıştır.

Eskişehir Osmangazi Üniversitesi idari personelinin aylık gelirleri ile stres boyutlarının varyans analizi sonuçları Tablo 9'daki gibidir.

Tablo 9. Eskişehir Osmangaz̧ Üniversitesinde Calısan İdari Personelin Aylık Gelirlerine Göre Stres Boyutlarmın ANOV A Sonuclar

\begin{tabular}{|c|c|c|c|c|c|c|}
\hline & & Kareler & sd. & Kareler Ortalaması & $\mathbf{F}$ & $\mathbf{P}$ \\
\hline \multirow{3}{*}{ İş Koşulları } & Gruplar Arası & 19,203 & 4 & 4,801 & 5,323 & 0,001 \\
\hline & Gruplar İçi & 139,797 & 155 & 0,902 & & \\
\hline & Toplam & 159,000 & 159 & & & \\
\hline \multirow{3}{*}{ Sorumluluklar } & Gruplar Arası & 5,834 & 4 & 1,458 & 1,476 & 0,212 \\
\hline & Gruplar İçi & 153,166 & 155 & 0,988 & & \\
\hline & Toplam & 159,000 & 159 & & & \\
\hline \multirow{3}{*}{ İş Arkadaşları } & Gruplar Arası & 11,847 & 4 & 2,962 & 3,120 & 0,017 \\
\hline & Gruplar İçi & 147,153 & 155 & 0,949 & & \\
\hline & Toplam & 159,000 & 159 & & & \\
\hline \multirow{3}{*}{ İletişim } & Gruplar Aras1 & 2,402 & 4 & 0,601 & 0,594 & 0,667 \\
\hline & Gruplar İçi & 156,598 & 155 & 1,010 & & \\
\hline & Toplam & 159,000 & 159 & & & \\
\hline
\end{tabular}

Tablo 9 incelendiğinde sorumluluklar $(\mathrm{p}=0,212)$, iletişim $(\mathrm{p}=0,667)$ stres boyutlariyla, idari personelin aylık gelirleri arasında anlamlı bir fark bulunamamıstır. İş koşulları $(F=5,323 ; p=0,001<0,05)$, iş arkadaşları 
$(\mathrm{F}=3,120 ; \mathrm{p}=0,017<0,05)$ stres boyutlarıyla, idari personelin aylık gelirleri arasındaki karşılaştırmada ise anlamlı bir fark olduğu anlaşılmıştır.

İş arkadaşları ve idari personelin aylık gelirleri arasındaki farklılığın araştırılmasında grupların varyanslarının homojen olması nedeniyle çoklu Tukey testiyle analiz yapılmış ve aylık gelirleri 1500TL'den az olan idari personelin, iş arkadaşlanı stres boyutunun daha fazla olduğu anlaşılmıştır.

İş koşulları ve idari personelin aylık gelirleri arasındaki farklılı̆ı̆n incelenmesinde, grupların varyanslarının homojen olmaması nedeniyle Tamhane's T2 testiyle analiz yapılmış ve aylık gelirleri 15002000TL olan idari personelin, iş koşulları stres boyutunun 2000-4000TL arasında olanlara göre daha az olduğu anlaşılmıştır.

Eskişehir Osmangazi Üniversitesi idari personelinin ünvanlarına göre stres boyutlarının varyans analizleri sonuçları aşağıdaki Tablo 10'daki gibidir.

Tablo 10. Eskişehir Osmangazi Üniversitesinde Calsşan İdari Personelin Unvanlarna Göre Stres Boyutlarmm ANOV A Sonuclar

\begin{tabular}{|c|c|c|c|c|c|c|}
\hline & & Kareler Toplamı & sd. & Kareler Ortalaması & $\mathbf{F}$ & $\mathbf{P}$ \\
\hline \multirow{3}{*}{ İş Koşulları } & Gruplar Aras1 & 10,248 & 3 & 3,416 & 3,582 & 0,015 \\
\hline & Gruplar İçi & 148,752 & 156 & 0,954 & & \\
\hline & Toplam & 159,000 & 159 & & & \\
\hline \multirow{3}{*}{ Sorumluluklar } & Gruplar Aras1 & 1,002 & 3 & 0,334 & 0,330 & 0,804 \\
\hline & Gruplar İçi & 157,998 & 156 & 1,013 & & \\
\hline & Toplam & 159,000 & 159 & & & \\
\hline \multirow{3}{*}{ İş Arkadaşları } & Gruplar Arası & 7,456 & 3 & 2,485 & 2,558 & 0,057 \\
\hline & Gruplar İçi & 151,544 & 156 & 0,971 & & \\
\hline & Toplam & 159,000 & 159 & & & \\
\hline \multirow{3}{*}{ İletişim } & Gruplar Aras1 & 6,462 & 3 & 2,154 & 2,203 & 0,090 \\
\hline & Gruplar İçi & 152,538 & 156 & 0,978 & & \\
\hline & Toplam & 159,000 & 159 & & & \\
\hline
\end{tabular}

Tablo 10'a göre sorumluluklar $(\mathrm{p}=0,804)$, iş arkadaşları $(\mathrm{p}=0,057)$, iletişim $(\mathrm{p}=0,090)$ stres boyutlarıyla, idari personelin unvanlarıyla karşılaştırılması sonucunda anlamlı bir fark bulunamamıştır. İş koşulları $(\mathrm{F}=3,582 ; \mathrm{p}=0,015<0,005)$ stres boyutu ile idari personelin unvanları arasındaki karşılaştırmada anlamlı bir fark bulunmuştur.

Bu farkll1ık (grupların varyanslarının homojen olmaması nedeniyle) Tamhane's T2 testi ile analiz edilmiş ve müdürlerin iş koşulları stres boyutunun memurlara göre daha fazla olduğu anlaşılmıştır.

\section{Stres Faktörlerinin Yapısal Eşitlik Modeliyle(YEM) İncelenmesi}

Yapısal Eşitlik Modelleri(YEM); gözlenen değişkenler ile gözlenemeyen (gizil-latent) değişkenler arasındaki nedensel ve ilişkisel olarak tanımlanması amacıyla kullanılan bir istatistiksel tekniktir (Gürbüz ve Yilmaz, 2016, s. 199; Aydın ve diğerleri, 2011, s. 391).

Yapısal eşitlik modellerinin amacı, eldeki verilerden faydalanarak ortaya çıkan sonuçların değişimini doğru olarak ifade edebilen bir denklem modeli oluşturabilmektir. Yapısal eşitlik modelleri, çoklu regresyon ve faktör analizinin kombinasyonudur (Gefen vd., 2000; Turunç vd., 2010, s. 213).

YEM analizlerinde, bütünleşik modelin uyumuyla ilgili testler tek ve iki aşamalı analiz yaklaşımıyla ele alınmaktadır. İki aşamalı yaklaşımda ise, ölçüm modeli ve yapısal model ayrı ayrı test edilir. Tek aşamalı yaklaşımda ise araştırma modelinin yapısal ve ölçüm kısımları aynı anda analize dahil edilerek yapısal eşitlik modelinin sonuçlarının elde edilir (Güngör, 2018, s. 79-80). Bu araştırmada tek aşamalı yaklaşım yöntem benimsenmiştir. Tek aşamalı yaklaşım sonucunda elde edilen modelin grafiği aşağıdaki gibidir. 


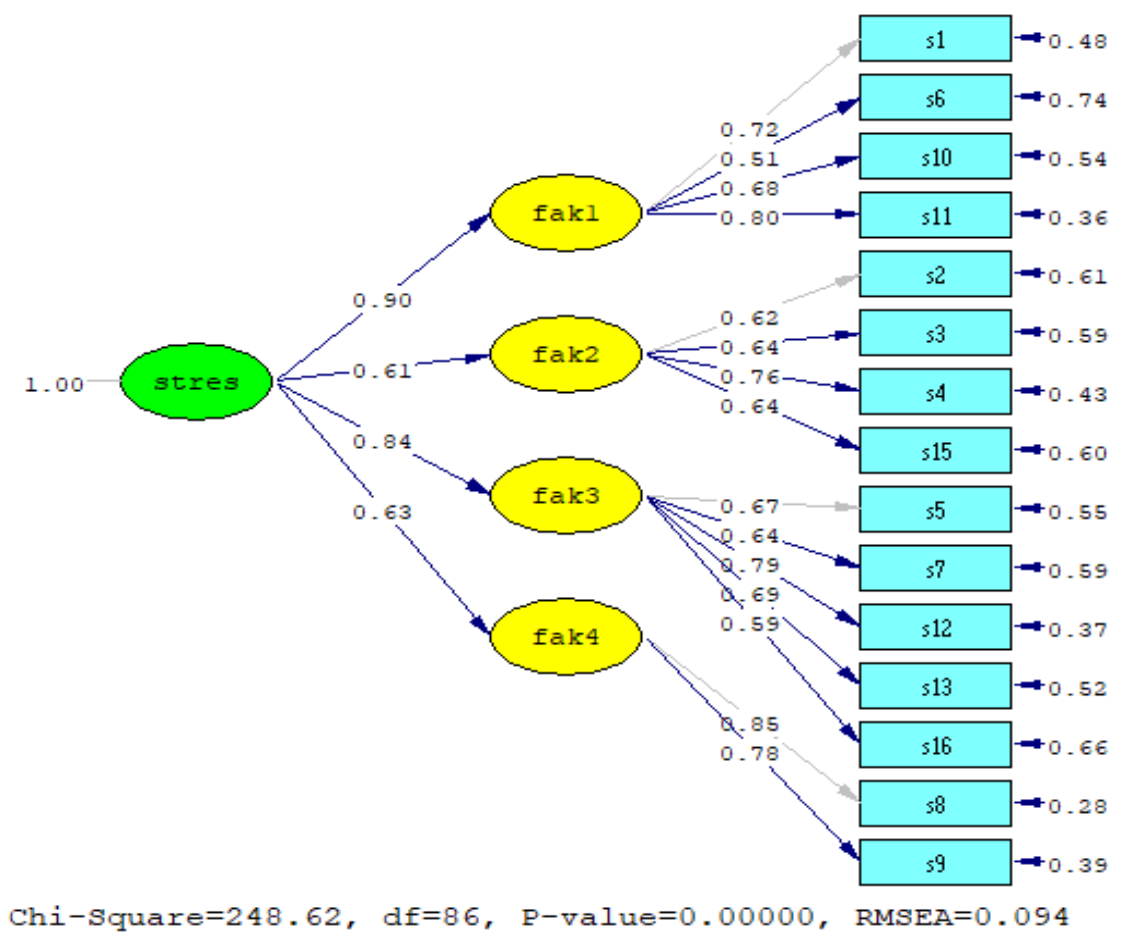

Grafik 1. Stres Path Grafigi

Stres path grafiğindeki faktörlerin açılımı sırasıyla; fak1 (iş koşulları), fak2 (sorumluluklar), fak3 (iş arkadaşları), fak4 (iletişim)'dir.

Standartlaştırılmış yükler her bir gözlenen değişkenle, ilgili olduğu gizil değişkenler arasındaki korelasyonları göstermektedir. Korelasyon katsayıları 0.51-0.85 arasında değer almaktadır. YEM modeline göre fak1'de s14 değişkenin katsayısı 0.50'nin altında olduğu için modelden çıkartılmıştır. Fak1'in değişkenliğini en çok s11 (0.80) gözlenen değişkeni tarafindan açıllandığı görülmektedir. Diğger faktörler incelendiğinde ise; fak2'yi s4 (0.76), fak3'ü s12 (0.79) ve fak4'ü en çok s8 (0.85) değişkeni açılklamaktadır. Buna göre stres modeli aşağıdaki gibidir:

\section{Stres $=0.90 \mathrm{fak} 1+0.61 \mathrm{fak} 2+0.84 \mathrm{fak} 3+0.64 \mathrm{fak} 4$}

Stres (YEM) modeli incelendiğinde; fak1'in bir birim artmas1 stres gizil değişkeninin 0.90 birim arttırmaktadır. Stresi arttıran ikinci faktör ise fak3'tür. Fak3'ün bir birim artmas1 stresi 0.84 birim arttırmaktadır. Daha sonra ise sırasiyla fak4 ve fak2 gelmektedir.

$\mathrm{Bu}$ durumda; Stresi açıklamada en önemli faktörün fak1 (iş koşulları) ve fak3 (iş arkadaşları) kaynaklandığını, bunları ise fak4 (iletişim) ve fak2 (sorumluluklar)'ın takip ettiği görülmektedir

Uyum iyiliği değerleri incelendiğinde ise; stres modelinin tutarlı olduğu tablo 11'de görülmektedir. $\chi^{2}=248.62, \mathrm{df}=86, \mathrm{p}=0.00000, \mathrm{RMSEA}=0.094, \mathrm{AGFI}=0.90, \mathrm{GFI}=0.93, \mathrm{CFI}=0.97$ ve NFI=0.93 değerlerinin kabul edilebilir uyum düzeyine işaret ettiği görülmektedir (Schermelleh-Engel vd. 2003: 52).

Tablo 11. Uyum İyilĭgi Değerleri

\begin{tabular}{lllll}
\hline Uyum Ölçüleri & \multicolumn{1}{c}{ İyi Uyum } & \multicolumn{1}{c}{ Kabul Edilebilir Uyum } & $\begin{array}{c}\text { Model } \\
\text { Uyumu }\end{array}$ & Sonuç \\
\hline$\chi^{2} / d f$ & $0 \leq \chi^{2} / d f \leq 2 d f$ & $2 d f \leq \chi^{2} / d f \leq 3 d f$ & 2,89 & Kabul Edilebilir Uyum \\
\hline RMSEA & $0,00 \leq \mathrm{RMSEA} \leq 0,05$ & $0,05 \leq \mathrm{RMSEA} \leq 0,10$ & 0,094 & Kabul Edilebilir Uyum \\
\hline NFI & $0,95 \leq \mathrm{NFI} \leq 1,00$ & $0,90 \leq \mathrm{NFI} \leq 0,95$ & 0,93 & Kabul Edilebilir Uyum \\
\hline CFI & $0,95 \leq \mathrm{CFI} \leq 1.00$ & $0,95 \leq \mathrm{CFI} \leq 0,97$ & 0,97 & Kabul Edilebilir Uyum \\
\hline GFI & $0,95 \leq \mathrm{GFI} \leq 1.00$ & $0,90 \leq \mathrm{GFI} \leq 0,94$ & 0,93 & Kabul Edilebilir Uyum \\
\hline AGFI & $0,90 \leq \mathrm{AGFI} \leq 1.00$ & $0,85 \leq \mathrm{AGFI} \leq 0,90$ & 0,90 & Kabul Edilebilir Uyum \\
\hline
\end{tabular}

Kaynak: Schermelleh-Engel vd. (2003, s. 52) 


\section{Tartışma, Sonuç ve Öneriler}

Stres hayatımızın kaçınılmaz bir parçasıdır. Bu durum yaşamımızın büyük bir bölümünü geçirdiğimiz iş hayatımızda etkisini daha çok hissettirmektedir. Ülkemizde özel sektöre kıyasla kamu sektöründe çalışma koşullan daha iyi olmakla beraber yine de artan kişisel beklentilerle birlikte çalışanlanı yeterince memnun etmemektedir.

Günümüzde gelişen çevre koşulları içerisinde kamu kurumlarının da belirli kalıplardan çıkması gerekmektedir. Bunu sağlayabilmek için kamu yöneticilerinin çalş̧anların memnuniyetini arttırmayı ön planda tutmaları gerekmektedir.

Çalışma hayatına girişte çalışanların yapacağı işle, iş ortamı ile ilgili beklentileri oldukça yüksek olmaktadır. Ancak çalışanların büyük çoğunluğu iş hayatında beklentilerinin önemli bir kısmını bulamamakta ve bu konuda stres yaşamaktadırlar. Benzer durum aynı kurumda uzun yıllar çalışanların yıllarca vermiş olduğu hizmet nedeniyle beklentilerini bulamaması durumunda da ortaya çıkmaktadır.

Çalışmada iş arkadaşları ile ilgili en fazla stres yaşan grubun 1500 TL'den az gelire sahip olan çalışanlar olduğu görülmektedir. Bu durum gelirin yükselmesi ile stresin azaldığını göstermekle birlikte, kamuda maaşların eğitim, çalışma yllı, unvana göre yükselmesi nedeniyle daha düşük maaş alanların daha az sorumluluk gerektiren işleri yapıyor olmaları nedeniyle iş arkadaşlarına karşı daha negatif tutum sergilediklerini göstermektedir.

İş hayatına başlangıçta çalışanların gerek adaptasyon gerekse iş arkadaşlarını tanıma süreci nedeniyle ilk yıllarda daha çok iletişim sorunu yaşamaktadırlar. Ancak geçen yıllarla birlikte özellikle aynı kurumda uzun yıllar çalışanlar birbirlerini ailelerinden bir parça gibi görmekte ve iletişim sorunları daha az yaşanmaktadır. İletişim boyutunda eğitim düzeyi de çalışma hayatında önem arz etmektedir. Eğitim seviyesi düşük çalışanların daha fazla iletişim sorunu yaşadığı görülmektedir.

Stressiz bir yaşam sağlanabilmesi ne kişilerin ne de kurumların sağlayabileceği bir durumdur. Bu nedenle stresle başa çıkabilmek için sorunun kaynağında çözümlenmesi gerekmektedir. Bu bağlamda stresle baş etmenin en iyi yolunun, strese sebep olan şeyleri belirleyerek kontrol altına almasıyla mümkün olabileceği söylenebilir. Bunun için çalışanların çalıştıkları kurumlarda daha huzurlu, mutlu ve verimli olmalarını sağlayıcı fiziksel, sosyal ve psikolojik ortamlar ve politikalar belirlenerek çalışan memnuniyeti arttırlabilir.

Araştırmada stresle ilgili yapısal eşitlik modeline göre de stresin en önemli faktörünün, iş koşullarından ve iş arkadaşlarından kaynaklandığı görülmektedir. Bu durumda Eskişehir Osmangazi Üniversitesinde çalışan personelin iş stresini azaltmak için öncelikle iş koşullarının düzenlenmesi, çalışan personelin iş arkadaşlarıyla uyum içinde çalışabileceği ortamların hazırlanması veya aynı ortamda uyumsuz kişilerin farklı ofislere alınarak iş arkadaşlarından kaynaklanan stresin azaltılması gerekmektedir. Çalışanların birbiriyle ve amirleriyle olan iletişimleri saygı çerçevesinde yürütülmelidir. Aynı işleri yapan personele eşit sorumluluklar verilmelidir.

\section{Etik Beyan}

"Ișs Stresi ve Eskişehir Osmangaž Üniversitesi İdari Personel Üzerine Bir Araştırma” başlıklı çalışmanın yazım sürecinde bilimsel, etik ve alıntı kurallarına uyulmuş; toplanan veriler üzerinde herhangi bir tahrifat yapılmamış ve bu çalışma herhangi başka bir akademik yayın ortamına değerlendirme için gönderilmemiştir.

\section{Teşekkür}

Verilerin toplanmasında yardım eden, ESOGÜ personeli ve aynı zamanda yüksek lisans öğrencim olan Rüveyda Doğan'a teşekkür ederim.

\section{Kaynakça}

Akgündüz, S. (2006). Örgütsel stres kaynaklarmm çalş̧anlarn iş tatmini üzerindeki etkisi ve banka çalı̧anlar için yapılan bir araştırma (Yüksek Lisans Tezi). Dokuz Eylül Üniversitesi Sosyal Bilimler Enstitüsü, İzmir.

Arıcan, K., (2011). Örgütsel stres kaynakları: Kavramsal bir çözümleme. Eğitim ve İnsani Bilimler Dergisi: Teori Ve Uygulama, 2(4), 55-76.

Artan, І. (1986). Örgütsel davranıs, örgütsel stres kaynaklar ve yöneticiler üzerinde bir uygulama. İstanbul Basisen Eğitim ve Kültür Yayınları. 
Aydın, İ. (2008). İs yaşamında stres. Ankara: Pegem Yayınevi.

Aydın, Ş. (2004). Örgütsel stres yönetimi. Dokuz Eylül Üniversitesi Sosyal Bilimler Enstitüsü Dergisi, 6(3), 23-48.

Aydın, A., Üçüncü, K. ve Taşdemir, T. (2011). Akademik performansı etkileyen stres kaynaklarının belirlenmesine yönelik bir alan çalışması. Uluslararası Insan Bilimleri Dergisi, 8(2), 387-389.

Baltaş, A. ve Baltaş, Z. (1998). Stres ve bașa çıkma yolları. Remzi Kitabevi, İstanbul.

Cam, E. (2004). Çalışma yaşamında stres ve kamu kesiminde kadın çalışanlar. Uluslararası İnsan Bilimleri Dergisi, 1(1), 110.

Ceylan, A. ve Ulutürk, Y. H. (2006). Rol belirsizliği, rol çatışması, iş tatmini ve performans arasındaki ilişkiler. Doğus Üniversitesi Dergisi, 7(1), 48-58.

Cüceloğlu, D. (1994). Insan ve davranısı. Psikolojinin temel kavramları. İstanbul: Remzi Kitabevi.

Davis, K. ve Newstrom, J.W. (1988). Organizatianol behavior; Human behavior at work (Ninht Edition). New Jersey: Mcgraw-Hill, Inc

Erdoğan, İ. (1999). İsletme yönetiminde örgütsel davranış. İstanbul: Dönence Basım ve Yayın Hizmetleri.

Ergül, A. (2010). Calıs̆ma yaşamında stresin bireysel performans üzerindeki etkileri: eğitim ve sağllk çalşsanlarna yönelike bir araștırma (Yüksek Lisans Tezi). Balıkesir Üniversitesi Sosyal Bilimler Enstitüsü, Balıkesir.

Gefen, D., Straub W. D. ve Boudreau M. C. (2000). Structural equation modelling and regression: Guidlines for research practice. Communications of The Association for Information Systems, 4(7), 1-80.

Gökdeniz, İ. (2005). Üretim sektöründeki işletmelerin örgüt içi stres kaynakları ve mobilyac1lik sektöründe bir uygulama. Selçuk Üniversitesi Sosyal Bilimler Enstitüsü Dergisi, 13, 173-189.

Göksel, A. ve Tomruk, Z. (2016). Akademisyenlerde stres kaynakları ile stresle başa çıkmada ve stres durumunda gösterilen davranışların ilişkisi. Türkizye Sosyal Araştırmalar Dergisi, 20, 315-343.

Güçlü, N. (2001). Stres yönetim. Gaði Üniversitesi Eğitim Fakültesi Dergisi, 21(1) 9-14.

Gül, H. (2007). İş stresi, örgütsel sağlık ve performans arasındaki ilişkiler: Bir alan araştırması. KMU İIBF Dergisi, $9(13), 318-332$.

Güler, Z., Başpinar, N. Ö., Gürbüz, H. (2001). İs yaşamında stres ve kamu kurumlarndaki sekreterler üzerine bir uygulama. Eskișehir: Anadolu Üniversitesi Yayınları.

Güngör, A. A. (2018). Etkili okul özelliklerinin dönüsümsel liderlik ve ögretmen bağhluğgyla ilişkisi (Doktora Tezi). Ege Üniversitesi Sosyal Bilimler Enstitüsü, İzmir.

Gürbüz, H. ve Yılmaz, V. (2016). Muhasebe meslek etiğine ilişkin algıların yapısal eșitlik modellemesiyle incelenmesi: eskişehir il merkezinde bir uygulama. Global Business Research Congress (GBRC), May 26-27, Istanbul.

Gürbüz, H., Doğan, R., Görmüş, E., Tokyay, G. P., Öztekin D. ve Engiz, G. (2014). Kamu çalışanlarının stres düzeylerinin ölçülmesi ve eskişehir kamu çalışanları üzerine bir araştırma. Eskişehir Osmangaẓi Üniversitesi Sosyal Bilimler Dergisi, 15(1), 113-132.

Johnstone, M. (1989). Stress in teaching. An overwiew of research. midlothian: The Scottish Council For Research In Education. SCRE Publication.

Kalayc1, S ve diğerleri, (2006). SPSS uygulamal çok değģskenli istatistik teknikler. Ankara: Asil Yayın Dağıtım.

Karakaş, A. ve Gökmen, G. (2018). Kamu çalışanlarında iş tatmini, duygusal emek ve iş stresi: konya'da bir araştırma. AIBÜ Sosyal Bilimler Enstitüsü Dergisi, 18(3), 99-127.

Karakaya, A. ve Ay, F. A. (2007). Çalışanların Motivasyonunu etkileyen faktörler: sağlık çalışanlarına yönelik bir araștırma. C.Ü. Sosyal Bilimler Dergisi, 31(1), 55-67.

Karasakal, N. ve Yücebalkan, B. (2017). İş sağllğı ve güvenliği uygulamalarının çalışanların stres düzeylerine etkisi ile demografik özellikler - stres ilişkisini ortaya koymaya yönelik alan araştırması. Sosyal Bilimler Dergisi, 4(12), 375385.

Keser, A., https://www.academia.edu/1473010/ Güncel Yaklaşımlarla Stres Ve Kaynakları. Türk Metal. s. 48-54. (Erişim 23.06.2019).

Köse, H., (2015). Örgütlerde stres kaynaklar1 ve stres yönetimi. Anadolu Bil Meslek Yüksekokulu Dergisi. http://www.haticekose.com.tr/orgutlerde-stres-kaynaklari-ve-stres-yonetimi/ (Erişim 23.06.2019).

Lazarus, R., Folkman, S. (1984). Stress, appraisal and coping. Sprin-Ger Publishing Company.

Luthans, F. (1992). Organizational behavior. New York: Mc Graw Hill Inc.

Pehlivan, İ. (1992). Örgütsel stres kaynakları ve verimlilik. Ankara Üniversitesi Eüitim Bilimleri Fakültesi Dergisi, 24(2), 791-802.

Pehlivan, İ. (1995). Yönetimde stres kaynaklar. Ankara: Personel Geliştirme Merkezi Yayınları.

Queeensland Healt (2001). Healthy Island Resorts: Stress at Work. Queens and Government Tropical Public Health Unit Network Queensland Goverment.

Robbins, S. P. (2003). Organizational behavior. New Jersey: Pearson Education International Inc.

Schermelleh, E. K. ve Moosbrugger, H. (2003). Evaluating the fit of structural equation models: Tests Of significance and descriptive goodness-of-fit measures. Methods of Psychological Research, Online, 8(2), 23-74.

Selye H. (1956). The stress of life. New York: McGraw-Hill Book Co.

Selye H. (1974). Stress without distress. New York: J:B. Lippincott

Serinkan, C., Kaymakçı, K., Alişan U., Avcık, C. (2012). Kamu sektöründe örgütsel stres ve kariyer: Denizli'de yapılan bir araştırma. Organizasyon ve Yönetim Bilimleri Dergisi, 4(1), 21-32.

Soysal, A. (2009). İş yaşamında stres. http://www.ceis.org.tr/dergiDocs/makale237.pdf(Erişim 23.06.2019). 
Tekin, G. Ö. (2010). Çalışma Yaşamında stres kaynakları ve kamu kurumlarında çalışanlar üzerine etkileri: Edirne örneği (Yüksek Lisans Tezi). Trakya Üniversitesi Sosyal Bilimler Enstitüsü, Edirne.

Turunç, Ö., Tabak, A., Şeşen, H. ve Türkyılmaz, A. (2010). Çalışma yaşamı kalitesinin prosedür adaleti, iş tatmini, iş stresi ve işten ayrilma niyetine etkisi. "İş, Gǚs" Endüstri İlişkileri ve İnsan Kaynaklar Dergisi, 12(2), 115-134.

Tutar, H., Yılmaz, M. K. ve Erdönmez, C. (2006). Issletme becerileri grup çalıs̆ması (4. Baskı). Anakara: Detay Yayıncılık.

Yıldız, N. Ç. ve Güneş, M. Ş. (2017). Örgütsel stresin, örgütsel sessizlik ve tükenmişlik üzerine etkisi: Eczane çalışanları üzerinde bir araştırma. Uygulamah Sosyal Bilimler Dergisi, 1(1), 45-66.

Yenihan, B., Öner, M. ve Çiftyıldız, K. (2014). İşs stresi ve işten ayrılma niyeti arasındaki ilişki: Otomotiv işletmesinde bir araştırma. Calışma İliskileri Dergisi, 5(1), 38-49.

Yüksel, H. (2014). Çalışma yaşamı ve stres kavramı: durumsal bir yaklaşım. Manas Sosyal Araștırmalar Dergisi, 3(3), 109131.

Yürür, S. ve Keser A. (2011). İşe bağlı gerginlik ile iş tatmini ilişkisinde duygusal tükenmenin aracı rolü. Ankara Üniversitesi, Siyasal Bilgiler Fakültesi Dergisi, 65(4), 165-194.

\section{EXTENDED ABSTRACT}

Stress has now become a natural part of our lives. Regardless of the sector in which people work (public, private or free), it is inevitable that they will be introduced to the concept of stress as they continue to push their abilities and limits for the majority of their lives.

When the researches about stress in the literature are examined, the majority of them are banks, health institutions etc. which are thought to be more stressful institutions. It is seen on the application. The research was carried out to determine the effects of stress on employee performance; although it is an autonomous institution, it is examined through the questionnaire applied to the administrative staff of Eskişehir Osmangazi University which is a public institution.

The questions about stress sources in the second part of the questionnaire were obtained from the "Stress at Work "research.

5-point Likert Scale was used for the answers to the stress-related propositions. Participants were asked to fill out the option that best suits them. The data obtained from the research were analyzed using SPSS and Lisrel programs. The frequencies of the data obtained in the study were interpreted and the differences between the factors obtained as a result of factor analysis and demographic characteristics were examined by analysis of variance. In addition, the results obtained from factor analysis were tested with structural equation modeling (SEM).

Personal Information and the data obtained from the questionnaire applied to measure the effect of stress on employees can be summarized as follows. 82 of the 160 people $(51.2 \%)$ were female and 78 were male (48.8). As it can be seen from the table below, it is composed of people working for a long time due to the fact that $50.7 \%$ of the participants are between the ages of 35-45 (58 persons) and 45 years and older (23 persons). There are 92 people with undergraduate degrees, 24 with graduate and postgraduate degrees and it is seen that the level of education of the administrative staff participating in the survey is high. When the total working time is examined, it is understood that 58 people are between 10-20 years and 26 people are 20 years and over and have more experiences. Looking at the working time of the institution, it is understood that 15 people have been transferred to the University after having worked in another institution before when compared to the total working time of less than 1 year and 68 people between $1-5$ years.

As a result of the factor analysis, 4 factors were grouped in 16 expressions. These factors are respectively fak1: work conditions, fak2: responsibilities, fak3: colleagues, fak4: communication.

One-way analysis of variance was used to compare the differences of opinion of more than two groups such as age, education, total working time, working time in the institution, monthly income and titles, and the following results were obtained:

1)It was found that there was a significant difference between the stress conditions and the age of administrative staff $(\mathrm{F}=5,482, \mathrm{p}=0.0001<0.05)$.

In the investigation of the age group which caused this difference, it was found that the work conditions stress dimension of the administrative staff whose age range was 45 and above was higher.

2) Communication $(\mathrm{F}=3,048, \mathrm{p}=0.030<0.05)$ was found to be a significant difference between the stress dimension and the training of administrative staff. 
As a result of the post-hoc test, it was found that the communication stress dimension of secondary school graduates was higher.

3) It was found that there was a significant difference in the comparison between the stress conditions of work conditions $(\mathrm{F}=8,662, \mathrm{p}=0,0001<0,05)$, communication $(\mathrm{F}=3,609, \mathrm{p}=0,008<0,05)$ and the total working time of the administrative staff.

In the analysis of the group from which the difference between working conditions and working hours of administrative staff originates, it is understood that the working conditions stress dimension of the administrative staff whose work period is less than 1 year is higher.

It was understood that the communication stress dimension of the administrative staff with a working period of 1-5 years was higher.

4)Work conditions $(F=2,590, p=0,039<0,05)$, colleagues $(F=3,219, p=0,014<0,05)$, communication $(\mathrm{F}=2,719, \mathrm{p}=0,032<0,05)$ stress dimensions and administrative staff working in the institution.

-The working conditions of the employees whose working period is 1-5 years in the institution are less than the stress dimension and administrative staff of 20 years and over,

-The stress dimension of the administrative staff with co-workers whose work period is less than 1 year is less than the other groups,

- It was understood that the stress of communication in the institution was 1-5 years, and the stress of communication was less than the administrative staff of 5-10 years.

5)It was found that there was a significant difference in the comparison between the stress conditions and the monthly income of the administrative staff $(F=5,323, p=0,0001<0,05)$, colleagues $(F=3,120$, $\mathrm{p}=0,017<0,05)$.

In the comparison of the monthly income of colleagues and administrative staff, it was found that the stress level of the colleagues of the administrative staff whose monthly income is less than 1500TL is higher.

In the examination of the difference between the working conditions and the monthly income of the administrative staff, it was found that the stress conditions of the administrative staff whose monthly income was 1500-2000TL were less than those of the 2000-4000TL.

6)It was found that there was a significant difference in the comparison between the stress conditions of job conditions $(\mathrm{F}=3,582, \mathrm{p}=0.015<0.005)$ and the titles of administrative staff.

When it is investigated which group originates from this difference. it was understood that the stress conditions of the managers' job conditions were higher than the civil servants.

The stress equation obtained as a result of Structural Equation Model is as follows;

\section{Stress $=0.90 \mathrm{fak} 1+0.61 \mathrm{fak} 2+0.84 \mathrm{fak} 3+0.64 \mathrm{fak} 4$}

When the goodness of fit statistics are examined; our stress model is consistent. $\chi 2=248 . \mathrm{df}=86$, $\mathrm{p}=0.00000, \mathrm{RMSEA}=0.094, \mathrm{AGFI}=0.90, \mathrm{GFI}=0.93, \mathrm{CFI}=0.97$ ve $\mathrm{NFI}=0.93$

In the study, it is seen that the most important factor in explaining stress is fak1 (job conditions) and fak3 (colleagues), followed by fak4 (communication) and fak2 (responsibilities). 